\title{
Darier's Disease
}

\author{
Kounassegarane Deepika
}

\begin{abstract}
A sparse inherited condition named Darier's disease (DAR), which was initially identified by a famous French dermatologist, Jean Darier, is caused by the defect in the mutation of the ATPA2 gene. Darier's disease is mainly represented by crusty dark patches over the skin, rarely with exudates, and it is otherwise termed as Darier's white patches, keratosis follicularis, keratotic papules, or dyskeratotic follicularis. It is an autosomal disorder, and it is tested by genetic testing registry, skin biopsy, and by means of obtaining a familial history. Around $90 \%$ of the cases are treated by oral retinoids and topical application. Remaining cases need a surgical repair. The person affected with this disease may have chances of getting mood disorders.
\end{abstract}

Keywords: ATPA2 gene, Autosomal dominant condition, Keratosis follicularis, Oral retinoids.

Pondicherry Journal of Nursing (2020): 10.5005/jp-journals-10084-12138

\section{INTRODUCTION}

Darier's disease (DAR) is a sparse inherited condition caused by the alterations in the mutations of ATP2A2 gene. ${ }^{1}$ This gene is regulated by a catalyst (enzyme) called sarcoendoplasmic reticulum calcium (SERCA2) that helps to control the level of calcium $\left(\mathrm{Ca}^{+}\right)$ions within the cells. This defect in gene results in changes in their skin. Some of these are may be due to somatic mutations. ${ }^{2}$ It affects both genders and is not a communicable disease, but it often begins at the adolescent (later teenage) age. It commonly affects an individual with stunted growth. The worldwide prevalence of this illness is $1: 30,000$, and in India, it is $1: 100,000$ persons. $^{3}$

\section{Definition}

Darier's disease is aroused by defect in the mutation of ATP2A2 (ATPase sarcoplasmic/endoplasmic reticulum $\mathrm{Ca}^{2+}$ transporting 2) protein coding gene. The main symptom of this disease is white patches and crusty patches on the skin. Hence it is called as DarierWhite disease. ${ }^{1}$

\section{What is the Pathogenesis of the Disease?}

It mainly arises due to the transformation in the ATP2A2, a protein coding gene which is abundant to cause the disease, where ATP2A2 enhances SERCA2 enzyme or pump needed for calcium $\left(\mathrm{Ca}^{+}\right)$ shifting inside the cell. The alteration in the ATP2A2 gene influences the action of SERCA2, which results in complete loss of calcium $\left(\mathrm{Ca}^{+}\right)$ shifting toward cytoplasm endoplasmic reticulum (ER) calcium ions. Because for a standard living organisms, calcium $\left(\mathrm{Ca}^{+}\right)$level is important for the supportive structure and work of desmosomal cell proteins in addition to regulate cell cycle. The inadequacy of ATP2A2 gene causes the wasting of intracellular attachment, such as desmosomes termed as acantholysis, resulting in the outcome of linkage between keratinocytes shows the signs and symptoms. ${ }^{4}$

\section{How is it Presented?}

- Darier's disease is mainly presented with hyperkeratosis papules in seborrheic areas on the forehead, ears, neck, chest, thorax, groin, and back (Figs 1 and 2). ${ }^{5}$

- Oral manifestations include papules in the palatal and alveolar mucosa, are usually asymptomatic, and has a distinct odor (Fig. 3). ${ }^{5}$
Department of Mental Health Nursing, Kasturba Gandhi Nursing College, Sri Balaji Vidyapeeth, Puducherry, India

Corresponding Author: Kounassegarane Deepika, Department of Mental Health Nursing, Kasturba Gandhi Nursing College, Sri Balaji Vidyapeeth, Puducherry, India, Phone: +91 9629750987, e-mail: deepsdeeps7287@gmail.com

How to cite this article: Deepika K. Darier's Disease. Pon J Nurs 2020;13(2):43-45.

Source of support: Nil

Conflict of interest: None

- Palms and soles may become thickened with white dark crusty papules. The rashes become aggravated due to heat, humidity, and exposure to sunlight (Fig. 4). ${ }^{5}$

- In fingers, nails become fragile and V-shaped nicking are present at the tip of the nails with red and white longitudinal nail lines (Figs 5-7). ${ }^{5}$

\section{How is it Diagnosed?}

- Routine dental examination can identify the disease for the persons who are presented with oral manifestations. Skin biopsy has to be taken and histopathological examinations to

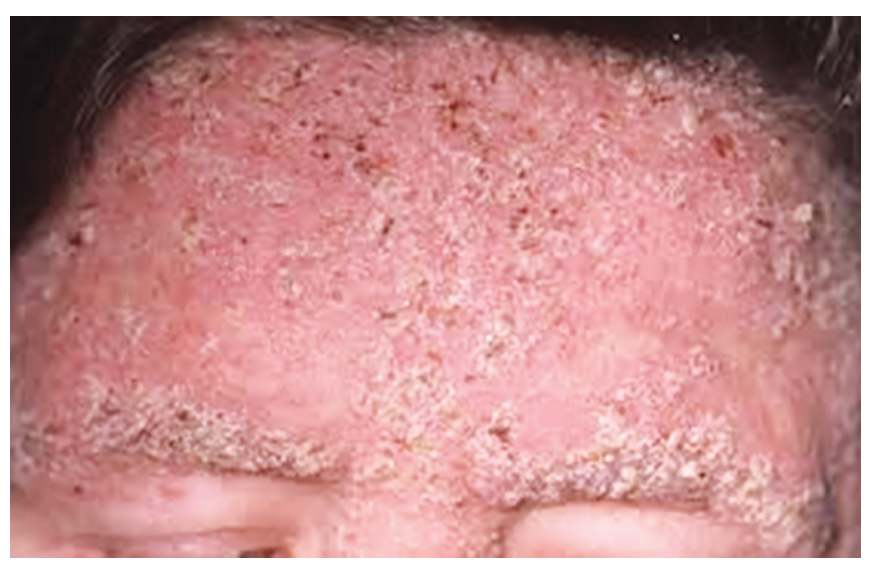

Fig. 1: Keratotic papules in the forehead

(c) The Author(s). 2020 Open Access This article is distributed under the terms of the Creative Commons Attribution 4.0 International License (https://creativecommons. org/licenses/by-nc/4.0/), which permits unrestricted use, distribution, and non-commercial reproduction in any medium, provided you give appropriate credit to the original author(s) and the source, provide a link to the Creative Commons license, and indicate if changes were made. The Creative Commons Public Domain Dedication waiver (http://creativecommons.org/publicdomain/zero/1.0/) applies to the data made available in this article, unless otherwise stated. 


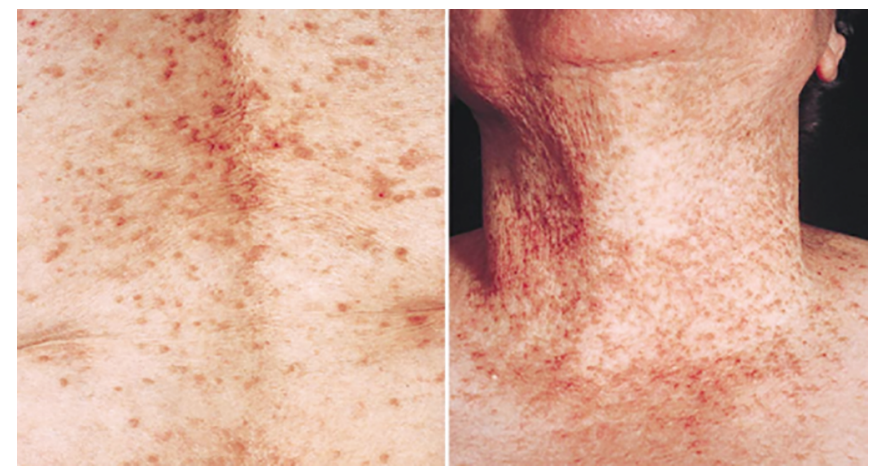

Fig. 2: Keratotic papules in the back and neck

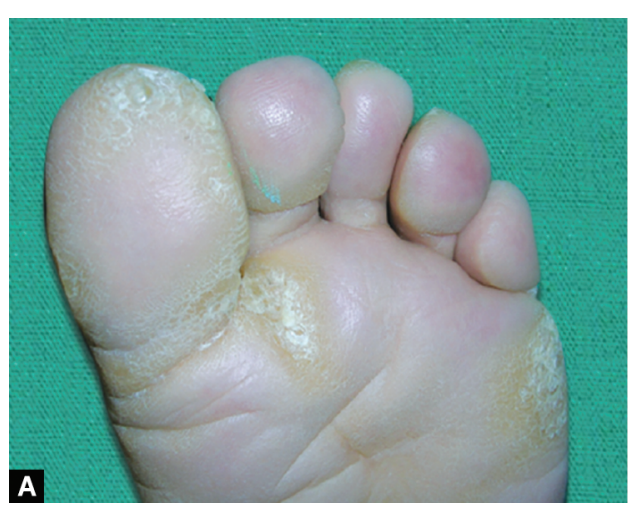

Fig. 4A and B: Papules: (A) On the sole; (B) On the palm

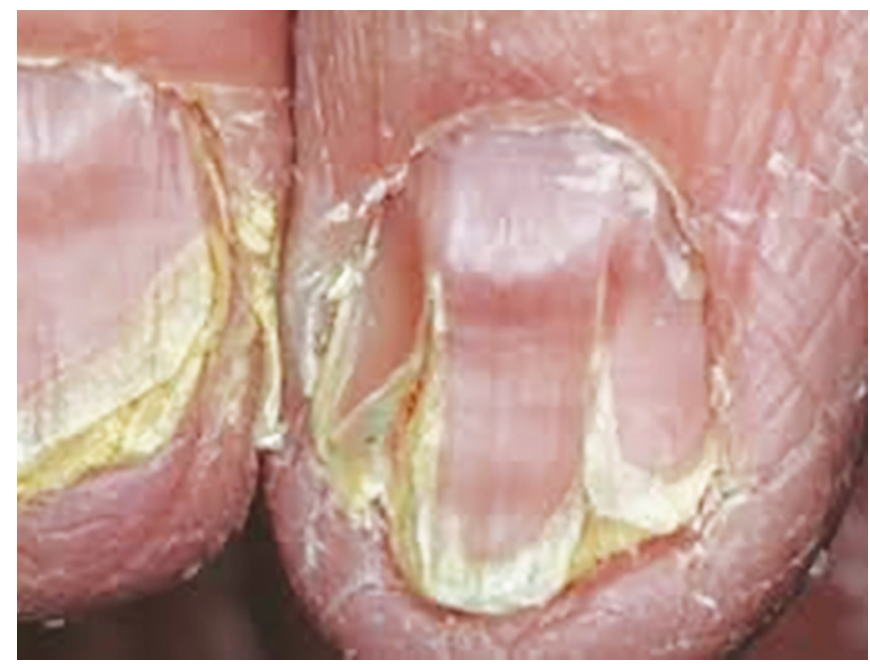

Fig. 5: Fragile nails

be done; the findings will show acantholytic and dyskeratotic cells in suprabasal clefts constituted with corps rods and grains. ${ }^{6}$

- Genetic testing can identify a defect in the ATP2A2, to certify the disease by the genetic testing registry (GTR) which gives facts regarding the particular genetic mutation. ${ }^{6}$

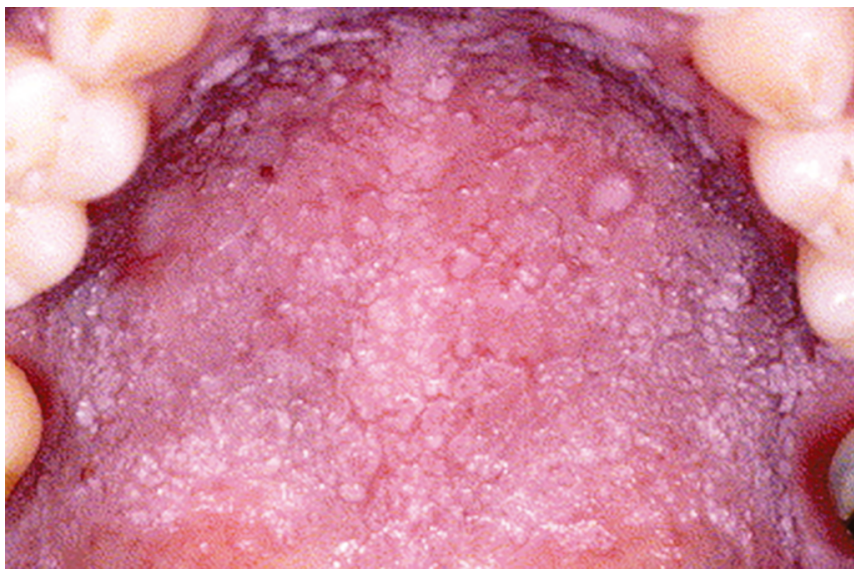

Fig. 3: Lesions in the oral cavity
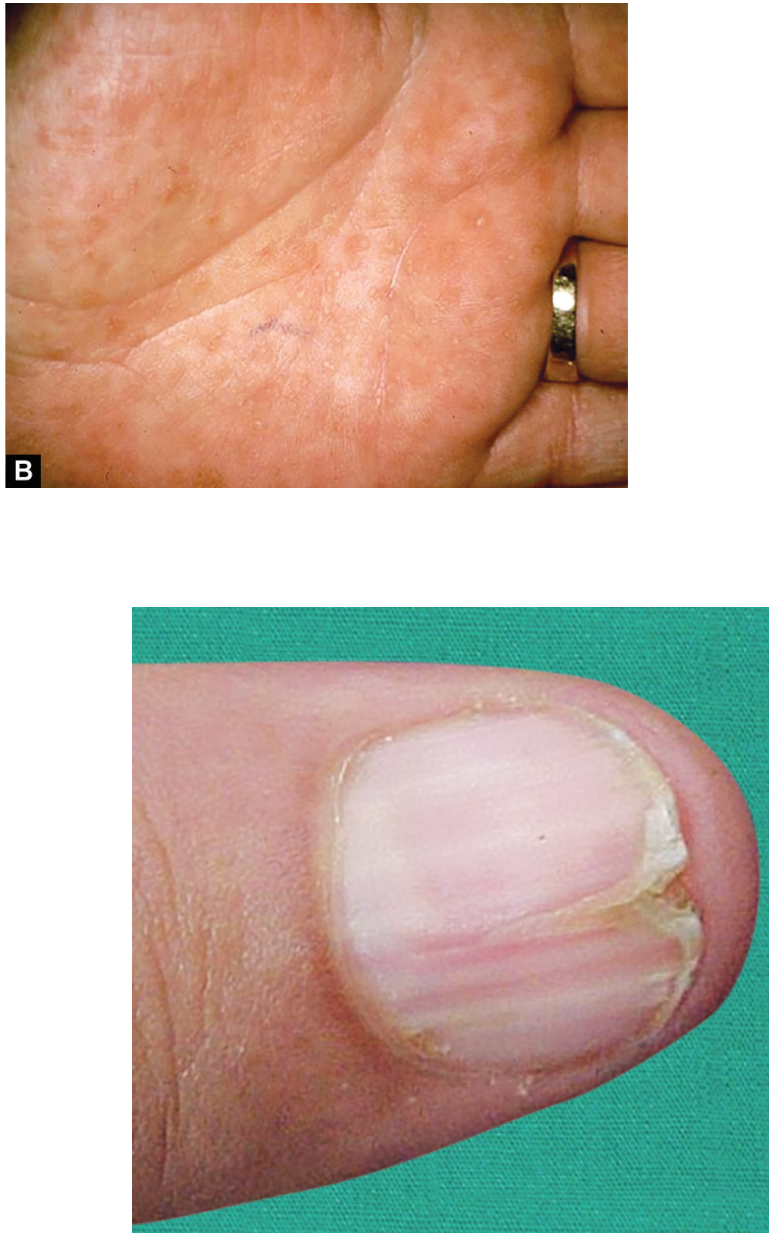

Fig. 6: V-shaped Nails

\section{What are the Treatment Measures?}

Darier's disease may not require any specific treatment. The minor forms of the disease can be treated by avoiding excessive exposure to heat, moisture, and stress, and compact clothes are advised, as well as maintaining good hygiene. Application of sunscreen lotions and oral supplementation of vitamin $C$ are very much essential to 


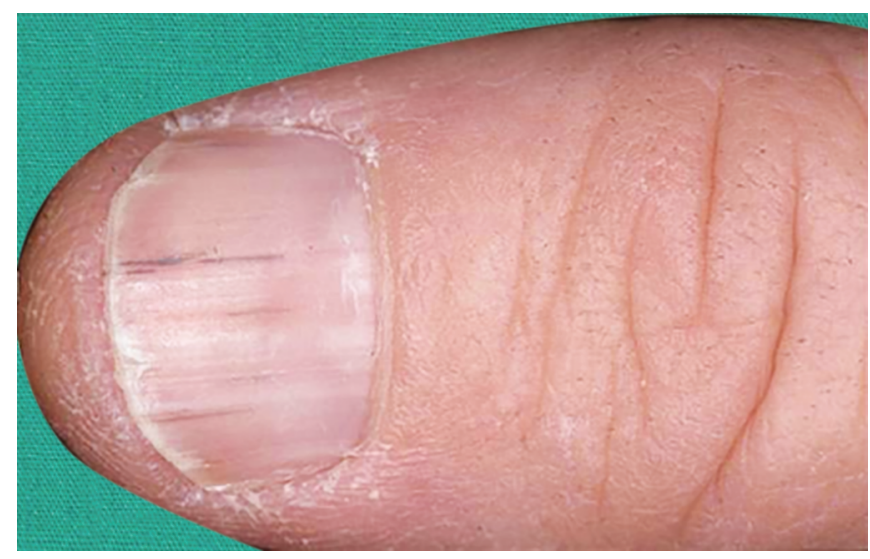

Fig. 7: Longitudinal line on the nail

prevent the spread of infection. Use of lotions and moisturizers such as topical application of lactic acid or urea can help to reduce the symptoms symptomatically, and topical creams such as benzoyl peroxide, isotretinoin, and topical diclofenac sodium are sometimes needed to overcome flare-ups. Chronic cases are treated with oral drugs given for retinoids (acitretin, isotretinoin, and alitretinoin), ciclosporin, topical corticosteroids, e.g., betamethasone does not have much side effects, so that it is given for 3 months as a treatment for Darier's disease. ${ }^{7}$

Not responding to drugs may lead to surgical correction such as destructive therapy, dermabrasion, surgical excision, electrosurgery, Mohs micrographic surgery, and photodynamic therapy. ${ }^{8}$

\section{Conclusion}

Darier's disease is an inherited dermatological disorder which is presented with carbuncle-like marks on the scalp, forehead, ears, chest, upper arm, back, oral cavity, nails, and soles palms. The severity of the disease varies from time to time. Most of the people are presented with linear or segmental form of Darier's disease, originated by alteration in the ATP2A2 protein coding gene. However, every affected individual may not require treatment, but the treatment includes the use of topical application as sunscreen and moisturizers, as well as staying cool. Surgical correction includes dermabrasion or electro surgery. ${ }^{1-3,7,8}$

\section{References}

1. Ringfeil F. Darier disease. NORD Guide to Rare Disorders. Philadelphia, PA: Lippincott Williams \& Wilkins; 2003. p. 101.

2. Rimoin D, Connor JM, Pyeritz RP, Korf BR. Emory and Rimoin's Principles and Practice of Medical Genetics. 4th ed., New York, NY: Churchill Livingstone; 2002. pp. 3913-3915.

3. Champion RH, Burton JL, Ebling FJG. Textbook of Dermatology. 5th ed., London, UK: Blackwell Scientific Publications; 1992 pp. 1362-1365.

4. James WD, Berger TG, Elston DM. Andrew's Diseases of the Skin: Clinical Dermatology. 10th ed., Saunders; 2005. pp. 567-568.

5. Byrne CR. The focal nature of Darier's disease lesions: calcium pumps, stress, and mutation? J Invest Dermatol 2006;126(4):702-703. DOI: 10.1038/sj.jid.5700141.

6. Ringpfeil F, Raus A, DiGiovanna JJ, Korge B, Harth W, Mazzanti C, et al. Darier disease-novel mutations in ATP2A2 and genotype-phenotype correlation. Exp Dermatol 2001;10(1):19-27. DOI: 10.1034/j.16000625.2001.100103.x.

7. Sehgal VN, Srivastava G. Darier's (Darier-White) disease/keratosis follicularis". Int J Dermatol 2005;44(3):184-192. DOI: 10.1111/j.13654632.2004.02408.x.

8. Apadin AN, Fleischmajer R. Tetracyclines: nonantibiotic properties and their clinical implications. J Am Acad Dermatol 2006;54(2): 258-265. DOI: 10.1016/j.jaad.2005.10.004. 